\title{
Pengaruh Ukuran Partikel Kulit Buah Kakao Terhadap Sifat Fisik, Mekanik dan Termal Papan Partikel dari Kulit Buah Kakao dan Serat Ampas Tebu
}

\author{
Ummi Salamah ${ }^{1, *}$, Muldarisnur ${ }^{1}$, Mora ${ }^{1}$, Yuli Yetri ${ }^{2, * * *}$ \\ ${ }^{1}$ Jurusan Fisika FMIPA Universitas Andalas, Padang, Indonesia \\ ${ }^{2}$ Jurusan Teknik Mesin, Politeknik Negeri Padang, Padang, Indonesia \\ *ummisalamaah@gmail.com \\ **yuliyetriyetri@gmail.com
}

\begin{abstract}
ABSTRAK
Telah dilakukan penelitian tentang pembuatan papan partikel dari kulit buah kakao dan serat ampas tebu yang bertujuan untuk menganalisis pengaruh ukuran partikel serbuk kulit buah kakao yang ditinjau dari sifat fisik, mekanik dan termal papan partikel. Parameter yang diukur adalah kadar air, densitas, daya serap air, kuat lentur, kuat patah, dan termal. Papan partikel ini dibuat dengan 5 variasi serbuk kulit buah kakao yaitu lolos ayakan 149, 177, 250, 400, dan $841 \mu \mathrm{m}$ dengan panjang serat ampas tebu $3 \mathrm{~cm}$. Komposisi bahan kulit buah kakao dan ampas tebu adalah 50:50 dan kadar perekat isosianat 16\%. Hasil sifat fisik didapatkan adalah nilai kadar air berkisar 9,27-13,05\%, nilai densitas berkisar $0,89-1,23 \mathrm{~g} / \mathrm{cm}^{3}$ dan nilai daya serap air berkisar 11,13-52,28\%. Hasil uji sifat mekanik didapatkan adalah nilai kuat lentur $2,8 \times 10^{3}-7,8 \times 10^{3} \mathrm{~kg} / \mathrm{cm}^{2}$ dan nilai kuat patah berkisar $1,43 \times 10^{4}-2,48 \times 10^{4} \mathrm{~kg} / \mathrm{cm}^{2}$. Hasil pengujian sifat konduktivitas termal didapatkan berkisar $7,26 \times 10^{-3}-9,0 \times 10^{-3} \mathrm{~W} / \mathrm{m}^{\circ} \mathrm{C}$. Ukuran partikel kulit buah kakao yang baik sebagai bahan pembuatan papan partikel adalah lolos ayakan $149 \mu$ m.Dari keseluruhan hasil pengujian disimpulkan bahwa ukuran partikel serbuk kulit buah kakao mempengaruhi pada sifat fisik, mekanik dan termal papan partikel. Semakin kecil ukuran partikel serbuk kulit buah kakao maka nilai densitas, kuat lentur, kuat patah dan konduktivitas termal papan partikel akan semakin tinggi. Pada pengujian kadar air dan daya serap air semakin kecil ukuran partikel kulit buah kakao maka semakin rendah nilai pengujian tersebut. Hasil penelitian menunjukkan bahwa sifat fisik dan mekanik papan partikel yang didapatkan pada pengujian telah memenuhi standar SNI 03-2105-2008 kecuali pada pengujian densitas dan kuat lentur. Berdasarkan persentase densitas papan partikel maka papan partikel yang dihasilkan termasuk jenis papan partikel berkerapatan tinggi.

Kata kunci: serbuk kakao, papan partikel, konduktivitas termal, sifat fisik, sifat mekanik.
\end{abstract}

\begin{abstract}
Research on the manufacturing of particle boards from cocoa peel and bagasse fiber which aims to analyze the effect of particle size of cocoa peel powder in terms of the physical, mechanical and thermal properties of particle boardshas been carried out. The parameters measured were water content, density, water absorption, flexural strength, fracture strength, and thermal. This particle board is made with 5 variations of cocoa fruit peel powder which are passed 149, 177, 250, 400, dan $841 \mu \mathrm{m}$ with a length of 3 $\mathrm{cm}$ bagasse fiber. The composition of the ingredients of cocoa pods and bagasse is 50:50 and the adhesive content of isocyanates is $16 \%$. The results of physical properties obtained were the value of water content ranged from 9.27-13.05\%, the density values ranged from 0.89 to $1.23 \mathrm{~g} / \mathrm{cm}^{3}$ and the value of water absorption ranged from 11.13 to $52.28 \%$. The results of the mechanical properties test were obtained by the value of flexural strength of $2.8 \times 10^{3}-7.8 \times 10^{3} \mathrm{~kg} / \mathrm{cm}^{2}$ and the value of broken strength ranged from $1.43 \times 10^{4}-2.48 \times 10^{4} \mathrm{~kg} / \mathrm{cm}^{2}$. The results of testing the properties of thermal conductivity were found around $7.26 \times 10^{-3}-9.0 \times 10^{-3} \mathrm{~W} / \mathrm{m}^{\circ} \mathrm{C}$. The size of the cocoa peel particles as a material for making particle board is passed through a $149 \mu \mathrm{m}$. From the overall test results it was concluded that the particle size of cocoa peel powder affects the physical, mechanical and thermal properties of particle board. The smaller the particle size of the cocoa peel powder, the higher the density, flexural strength, fracture strength and thermal conductivity of the particle board. In testing the moisture content and water absorption, the smaller the particle size of the cocoa peel, the lower the value of the test. The results of the study showed that the physical and mechanical properties of particle boards obtained in the tests met the standards of SNI 03-2105-2008 except in testing the density and flexural strength. Based on the percentage of particle board density, the particle board produced includes the type of high density particle board.
\end{abstract}

Keywords: cocoa powder, particle board, thermal conductivity, physical properties, mechanical properties. 


\section{PENDAHULUAN}

Tingginya kebutuhan akan kayu untuk bangunan, mebel, dan lain-lain mengakibatkan penyusutan pada luas hutan yang sangat signifikan. Salah satu usaha mengatasi permasalahan tersebut adalah pembuatan papan partikel dengan memanfaatkan limbah-limbah tumbuhan sebagai bahan baku.

Menurut Standar Nasional Indonesia tentang papan partikel (SNI.03-2105-2006), papan partikel adalah produk kayu yang dihasilkan dari hasil pengempaan panas antara campuran partikel kayu atau berlignoselulosa dengan perekat organik serta bahan pelengkap lainnya yang dibuat dengan cara pengempaan mendatar dengan dua lempeng datar. Papan partikel mempunyai beberapa kelebihan dibanding kayu asalnya, diantaranya papan partikel bebas cacat (mata kayu, pecah, dan retak) dan ukuran serta kerapatan papan dapat disesuaikan dengan kebutuhan (Maloney, 1993).

Banyak limbah pertanian yang mengandung lignoselulosa yang belum dimanfaatkan secara maksimal seperti ampas tebu dan kulit buah kakao. Selama ini pemanfaatan tebu masih terbatas pada industri gula dengan hanya mengambil airnya. Ampas tebu yang mencapai $35 \% 40 \%$ dari berat tebu hanya sebagian kecil dimanfaatkan sebagai bahan bakar industri, selebihnya dibuang sebagai limbah (Najihah dkk, 2018). Kulit buah kakao merupakan hasil buangan panen biji coklat yang paling besar volumenya. Produksi satu ton biji kakao kering menghasilkan sekitar 10 ton kulit buah kakao segar (Figueira dkk, 1993). Untuk mengatasi limbah kulit kakao dan ampas tebu tersebut perlu dilakukan pemanfaatan dengan menggunakannya sebagai bahan baku papan partikel.

Pembuatan papan partikel dengan bahan baku ampas tebu dan kulit kakao telah dilakukan oleh Najihah dkk (2018) dari penelitian tersebut dilakukan pengujian sifat fisis dan mekanis papan partikel dengan variasi komposisi bahan dan variasi perekat dengan ukuraan serbuk kulit buah kakao lolos ayakan 60 mesh $(250 \mu \mathrm{m})$. Hasil yang diperoleh adalah hamper seluruh pengujian papan partikel memenuhi standar SNI 03-2105-2006, JIS A 5908 (2003) dan FAO (1996). Namun pada pengujian nilai kuat patah beberapa papan tidak memenuhi standar.

Pengujian konduktivitas termal papan partikel telah dilakukan oleh Handani dkk (2010) dengan menggunakan sekam padi sebagai bahan utama. Penelitian tersebut menunjukkan bahwa papan sekam dengan diameter sekam kurang dari $1 \mathrm{~mm}$ memiliki sifat isolator panas yang paling baik dengan konduktivitas $0,187 \mathrm{~W} / \mathrm{m}^{\circ} \mathrm{C}$, tetapi dengan penambahan resin menurunkan kemampuan isolasi panas papan sekam.

Penggabungan serbuk kulit buah kakao dengan ampas tebu diharapkan akan menghasilkan papan partikel dengan sifat fisis, mekanis dan isolasi termal yang sesuai dengan SNI 03-2105-2006. Pada penelitian papan partikel ini dibuat dengan pencampuran serbuk kulit buah kakao dengan ampas tebu yang direkatkan dengan perekat isosianat dan menganalisis pengaruh variasi partikel serbuk kulit buah kakao lolos ayakan 149, 177, 250, 400, dan $841 \mu \mathrm{m}$ pada papan partikel. Komposisi papan partikel mengacu pada penelitian Najihah dkk (2018).

\section{METODE}

Penelitian ini dilaksanakan pada bulan September 2018 sampai Maret 2019. Bahan yang digunakan adalah kulit buah kakao, ampas tebu, perekat isosianat dan air. Peralatan yang digunakan sebagai berikut: neraca digital, Universal Testing Machine (UTM), ayakan (ukuran149, 177, 250, 400, dan $841 \mu \mathrm{m}$ ), hot press, ball milling, cetakan sampel ukuran $12 \mathrm{~cm} \times 8 \mathrm{~cm} \times 1 \mathrm{~cm}$, oven, jangka sorong, termometer, dan alat uji termal. Pembuatan sampel, pengujian sifat fisis dan sifat termal sampel dilakukan di Laboratorium Fisika Material Universitas Andalas. Pengujian sifat mekanis pada sampel dilakukan di Laboratorium Metalurgi Mekanik Politeknik Negeri Padang.

Tahapan pembuatan sampel adalah persiapan dan pengolahan pada bahan. Terlebih dahulu kulit buah kakao diiris tipis menggunakan pisau lalu dikeringkan dibawah sinar matahari selama 3 hari, kemudian dihaluskan untuk memperoleh ukuran serbuk yang dibutuhkan. Sedangkan ampas tebu direndam terlebih dahulu selama 2 jam untuk menghilangkan zat gula yang masih tersimpan pada ampas tebu, setelah itu dikeringkan dibawah sinar matahari selama 2 hari, lalu ampas tebu dibersihkan dari gabus guna mendapatkan serat dari ampas tebu tersebut. 
Bahan yang sudah disiapkan ditimbang sesuai dengan yang dibutuhkan. Perekat isosianat dicampur sampai homogen dengan serbuk kulit buah kakao dan serat ampas tebu lalu dimasukkan kedalam cetakan sampel secara merata. Tahapan selanjutnya adalah sampel dikempa panas selama 6 menit dengan suhu $150^{\circ} \mathrm{C}$ dengan tekanan $2,083 \mathrm{~N} / \mathrm{m}^{2}$, kemudian dilakuan pengkondisian pada sampel selama 7 hari dalam suhu ruang lalu dilakukan pengujian sifat fisik, sifat mekanik dan sifat termal pada sampel.

Pengujian sifat fisik dan mekanik papan partikel dilakukan berdasarkan standar SNI 032105-2006. Pengujian sifat fisik dengan parameter uji kadar air, densitas dan daya serap air. Pengujian sifat mekanik dengan parameter uji kuat lentur dan kuat patah. Sedangkan pengujian sifat konduktivitas termal dilakukan dengan metode plat rangkap.

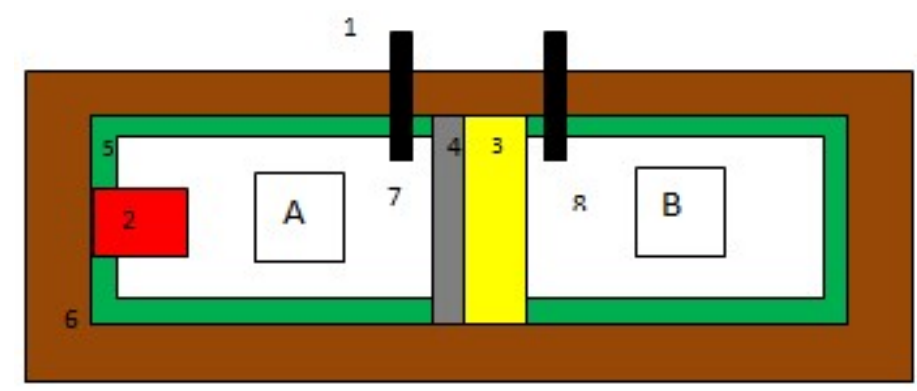

Gambar 1 Skema alat pengujian konduktivitas termal

Skema alat pengujian konduktivitas termal pada papan partikel terlihat pada Gambar 1 . Dimana warna coklat menunjukkan lapisan kayu, warna hijau adalah lapisan gabus, merah adalah sumber panas pada alat dengan daya 75 watt, abu-abu adalah plat aluminium, kuning adalah sampel yang akan diuji, dan hitam adalah termometer digital sebagai pengukur temperatur pada plat dan sampel uji.

\section{HASIL DAN DISKUSI}

\subsection{Uji Sifat Fisik}

\subsubsection{Kadar Air}

Hasil pengujian kadar air seperti pada Gambar 2 memperlihatkan nilai kadar air berkisar antara 8,62\%-12,08\%. Kadar air tertinggi dihasilkan oleh papan dengan ukuran partikel serbuk kulit buah kakao $841 \mu \mathrm{m}$ dan terendah $149 \mu \mathrm{m}$. Semakin kecil ukuran partikel serbuk kulit buah kakao maka nilai kadar air juga semakin menurun. Kadar air papan partikel juga dipengaruhi oleh kadar air bahan baku (Fauziah dkk, 2014). Semakin tinggi kadar air bahan baku maka semakin tinggi pula kadar air papan partikel yang dihasilkan, karena saat proses pengempaan tidak semua uap air dapat dikeluarkan dari papan (Mikael, 2014). Nilai kadar air papan partikel yang dihasilkan memenuhi standar SNI 03-2105-2006 yang mensyaratkan nilai kadar air maksimal $14 \%$.

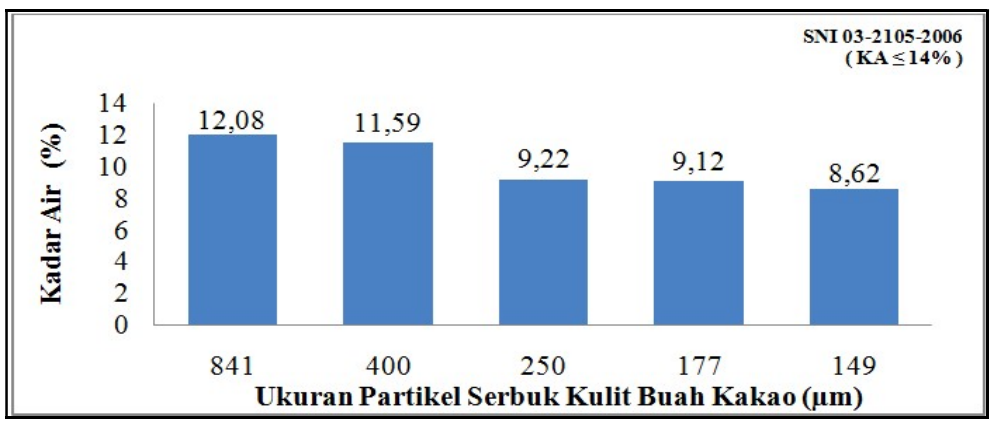

Gambar 2 Pengaruh ukuran partikel serbuk kulit buah kakao terhadap kadar air papan partikel 


\subsubsection{Densitas}

Nilai densitas papan partikel seperti Gambar 3 berkisar antara $0,89 \mathrm{~g} / \mathrm{cm}^{3}-1,23 \mathrm{~g} / \mathrm{cm}^{3}$. Semakin kecil ukuran partikel serbuk kulit buah kakao maka semakin besar nilai densitas papan partikel yang dihasilkan. Hal ini disebabkan karena berat jenis bahan baku yang digunakan kulit buah kakao dan serat ampas tebu, dimana berat jenis kulit buah kakao $\left(1,0204 \mathrm{~g} / \mathrm{cm}^{3}\right)$ lebih tinggi dibandingkan berat jenis ampas tebu $\left(0,12 \mathrm{~g} / \mathrm{cm}^{3}\right)$ sehingga memberikan peningkatan berat jenis papan partikel seiring semakin kecilnya ukuran serbuk kulit buah kakao. Semakin kecil ukuran partikel maka semakin tinggi densitas juga diperoleh Aminah (2018) dengan hasil densitas antara $0,69-0,71 \mathrm{~g} / \mathrm{cm}^{3}$. Berdasarkan Gambar 3 papan dengan ukuran partikel serbuk kulit buah kakao $841 \mu \mathrm{m}$ berada dalam interval SNI 03-2105-2006. Berdasarkan nilai densitas yang didapat variasi ukuran partikel serbuk kulit buah kakao yang memenuhi standar SNI 032105-2006 adalah $841 \mu \mathrm{m}$ dan lainnya lebih besar dari $0,9 \mathrm{~g} / \mathrm{cm}^{3}$ dapat dikategorikan kedalam papan partikel berkerapatan tinggi dimana nilai densitas papan partikel lebih dari $0,8 \mathrm{~g} / \mathrm{cm}^{3}$ (Maloney, 1993).

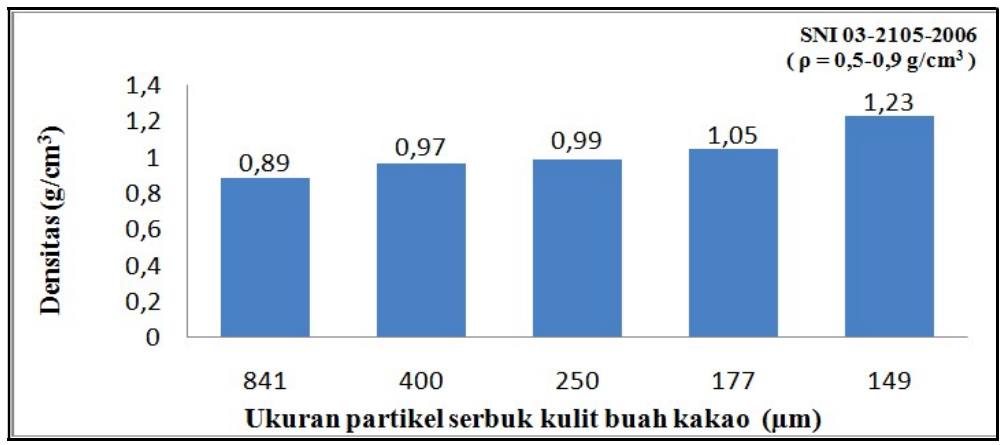

Gambar 3 Pengaruh ukuran partikel serbuk kulit buah kakao terhadap densitas papan partikel

\subsubsection{Daya Serap Air}

Nilai daya serap air seperti Gambar 4 memperlihatkan bahwa nilai daya serap air pada papan adalah berkisar antara 11,13\%-52,26\%. Semakin kecil ukuran partikel serbuk kulit buah kakao maka semakin kecil pula nilai daya serap air papan partikel. Hal ini disebabkan oleh partikel yang berukuran besar akan lebih mudah menyerap air. Lelana (2005) menyatakan bahwa kerapatan kayu berhubungan erat dengan perkiraan banyaknya rongga udara atau rongga sel sehingga semakin besar ukuran partikel semakin banyak rongga-rongga udara dan rongga tersebut akan diisi oleh air. Standar SNI 03-2105-2006 tidak mensyaratkan nilai daya serap air, namun pengujian ini tetap dilakukan sebagai pertimbangan untuk menentukan penggunaan dari papan partikel ini, apakah layak digunakan pada eksterior atau interior.

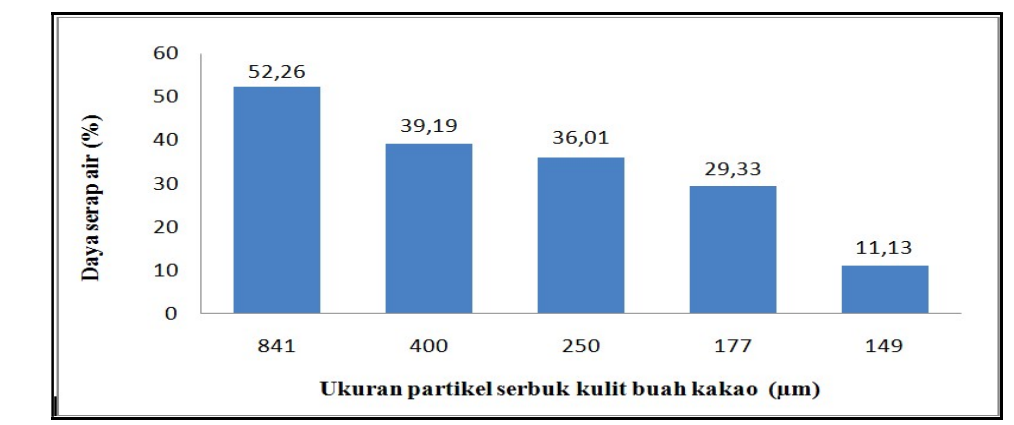

Gambar 4 Pengaruh ukuran partikel serbuk kulit buah kakao terhadap daya serap air papan partikel

\subsection{Uji Sifat Mekanik}

\subsubsection{Kuat Lentur}

Hasil pengujian kuat lentur yang terdapat pada Gambar 5 menunjukkan bahwa nilai kuat lentur papan partikel berkisar antara $2,8 \times 10^{3}-7,8 \times 10^{3} \mathrm{~kg} / \mathrm{cm}^{2}$. Nilai kuat lentur terendah terdapat 
pada papan dengan ukuran partikel serbuk kulit buah kakao $841 \mu \mathrm{m}$ dan nilai tertinggi pada 149 $\mu \mathrm{m}$. Semakin kecil ukuran partikel serbuk kulit buah kakao maka semakin tinggi nilai kuat lentur papan partikel. Sesuai dengan penelitian yang dilakukan Suroto (2010), yang melakukan penelitian papan partikel dari limbah rotan terhadap pengaruh ukuran partikel dan kadar perekat memperoleh nilai kuat lentur antara $547-6917 \mathrm{~kg} / \mathrm{cm}^{2}$. Hal ini disebabkan oleh semakin homogen papan partikel maka akan sedikit rongga udara yang terbentuk. Berdasarkan hasil pengujian yang didapat untuk semua variasi ukuran partikel serbuk kulit buah kakao belum memenuhi standar SNI 03-2105-2006 yang mensyaratkan nilai kuat lentur minimum 20.400 $\mathrm{kg} / \mathrm{cm}^{2}$.

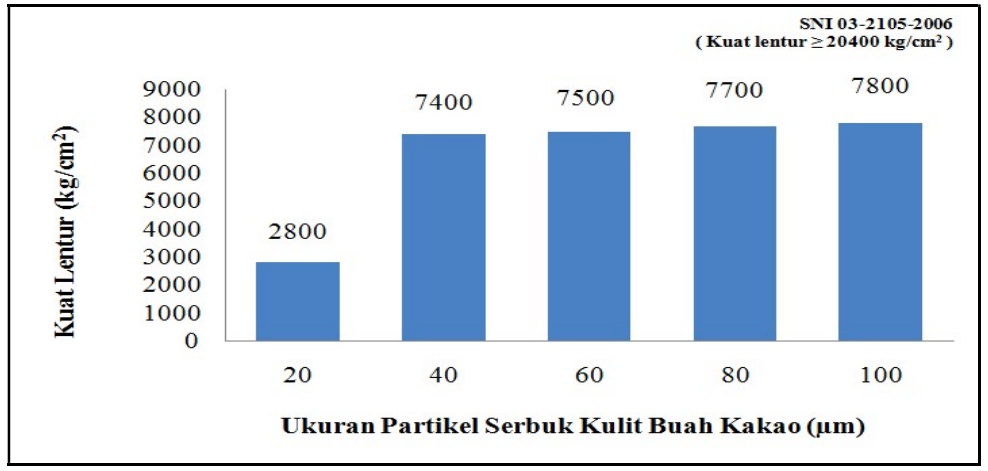

Gambar 5 Pengaruh ukuran partikel serbuk kulit buah kakao terhadap kuat lentur papan partikel

\subsubsection{Kuat Patah}

Gambar 6 menunjukkan hasil nilai pengujian kuat patah berkisar antara $1,43 \times 10^{4}$ $2,48 \times 10^{4} \mathrm{~kg} / \mathrm{cm}^{2}$. Nilai kuat patah terendah terdapat pada papan dengan ukuran partikel serbuk kulit buah kakao $841 \mu \mathrm{m}$ dan tertinggi adalah lolos $149 \mu \mathrm{m}$. Semakin kecil ukuran partikel serbuk kulit buah kakao maka semakin besar nilai kuat patah papan partikel. Sesuai dengan penelitian yang dilakukan Suroto (2010), yang menggunakan limbah rotan sebagai bahan penelitiannya memperoleh nilai kuat patah antara $115-1306 \mathrm{~kg} / \mathrm{cm}^{2}$. Hal ini disebabkan oleh partikel yang berukuran kecil memiliki ikatan yang lebih baik daripada partikel yang berukuran besar serta partikel-partikel kecil memiliki luas permukaan yang lebih besar daripada partikel yang berukuran besar. Nilai kuat patah yang didapat dari seluruh variasi ukuran partikel serbuk kulit buah kakao pada penelitian ini memenuhi standar SNI 03-2105-2006 yaitu minimal $82 \mathrm{~kg} / \mathrm{cm}^{2}$.

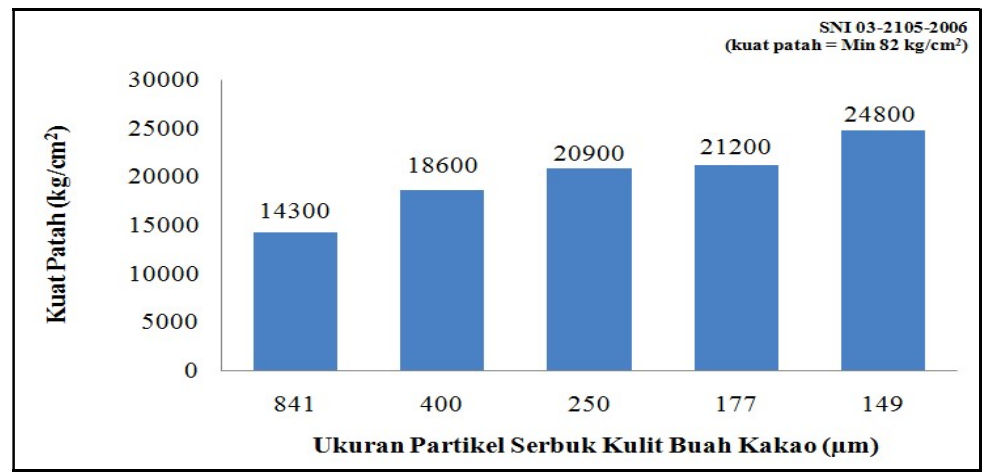

Gambar 6 Pengaruh ukuran partikel serbuk kulit buah kakao terhadap kuat patah papan partikel

\subsection{Uji Sifat Konduktivitas Termal}

Pengujian konduktivitas termal dilakukan untuk mencari tipe sampel yang memiliki sifat isolator yang baik. Gambar 7 menunjukkan bahwa nilai konduktivitas termal berkisar antara $7,26 \times 10^{-3}-9,0 \times 10^{-3} \mathrm{~W} / \mathrm{m}^{\circ} \mathrm{C}$. Semakin kecil ukuran partikel maka semakin kecil pula nilai konduktivitas termal papan. Sesuai dengan penelitian yang dilakukan Handani (2010), yang 
menggunakan sekam padi sebagai bahan penelitiannya dimana diperoleh nilai konduktivitas termalnya antara $0,187-0,329 \mathrm{~W} / \mathrm{m}^{\circ} \mathrm{C}$. Hal ini disebabkan karena ukuran partikel yang lebih kecil dapat tersusun lebih rapat sehingga meminimalisasi terbentuknya rongga-rongga dalam papan. Handani dkk (2010) menyatakan bahwa rongga-rongga yang terbentuk pada papan akan mengurangi sifat isolator panas papan karena menyebabkan proses konveksi di dalam papan. Menurut Wibowo (2008) bahan yang baik untuk isolator panas memiliki nilai konduktivitas termal sekitar $0,1 \mathrm{~W} / \mathrm{m}^{\circ} \mathrm{C}$.

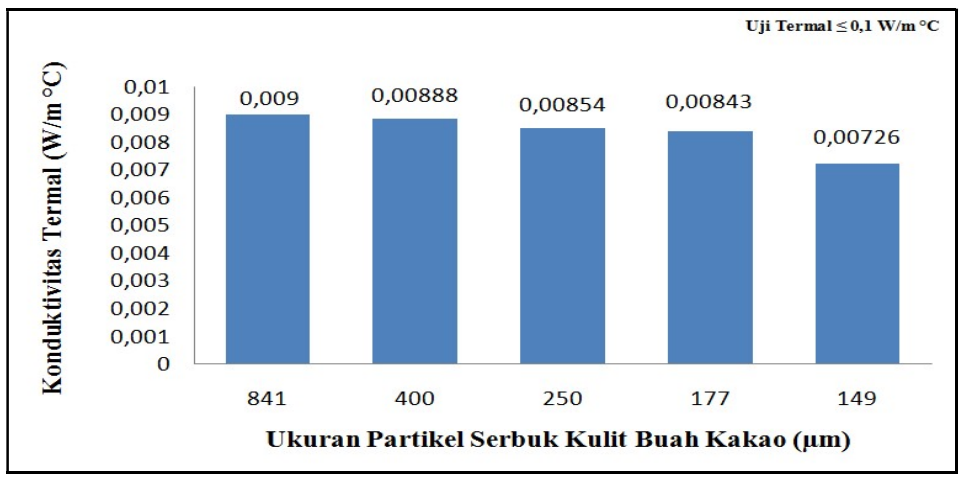

Gambar 7 Pengaruh ukuran partikel serbuk kulit buah kakao terhadap konduktivitas termal papan partikel

\section{KESIMPULAN}

Berdasarkan penelitian yang telah dilakukan dapat diambil kesimpulan bahwa adanya pengaruh ukuran partikel serbuk kulit buah kakao terhadap sifat fisis, mekanis dan termal papan partikel. Ukuran partikel kulit buah kakao yang baik sebagai bahan pembuatan papan partikel adalah $149 \mu \mathrm{m}$. Hasil menunjukkan bahwa nilai kadar air dan kuat patah memenuhi standar SNI 03-2105-2006. Semakin kecil ukuran serbuk maka semakin tinggi nilai konduktivitas termal. Berdasarkan nilai densitas maka papan partikel yang dihasilkan termasuk ke dalam papan partikel berkerapatan tinggi yang dapat digunakan untuk pembuatan dinding pemisah, pintu dan lain-lain.

\section{DAFTAR PUSTAKA}

Aminah, Setyawati, D., Yani, A., "Sifat Fisik dan Mekanik Papan Partikel dari Limbah Kayu Acacia crassicarpa Pada Beberapa Ukuran Partikel dan Konsentrasi Urea Formaldehida", Jurnal Hutan Lestari, 6, 557-568, (2018).

Fauziah, Wahyuni, D., Lapanporo, B.P., "Analisis Sifat Fisis dan Mekanik Papan Partikel Berbahan Dasar Sekam Padi”, Positron, 4, 60-63, (2014).

Figueira, A., Janick, J., Bemiller, Jn., New Products from Theobroma Cacao: Seed Pulp and Pod Gum, New Crops, Pp. 475-478, (1993).

Handani, S., Aprion, I., Mulyadi, S., danAdril, E., "Sifat Isolator Panas Papan Sekam Padi dengan Variasi Resin dan Ukuran Partikel”, Jurnal Ilmu Fisika, 2 (2), (2010).

Lelana, "Pengawetan Bagian Lunak Kayu Kelapa Secara Rendaman Dingin dengan Bahan Pengawet CCB", Info Hasil Hutan,11, 2, (2005).

Maloney, T., M., Modern Particle Board and Dry Process Fibre Board Manufacturing (Miller Freeman, Inc San Fransisco, 1993).

Mikael, I., Hartono, R., dan Sucipto, T., "Kualitas Papan Partikel dari Campuran Ampas Tebu dan Partikel Mahoni dengan Berbagai Variasi Kadar Perekat Phenol Formaldehida", Jurnal Kehutanan USU, 5, 1-8, (2014).

Najihah, Y., F.,Puryanti, D., Yetri, Y., "Pengaruh Komposisi Kulit Buah Kakao, Ampas Tebu, dan Perekat terhadap Sifat Fisis dan Mekanis Papan Partikel dari Campuran Limbah Kulit Buah Kakao dan Ampas Tebu", Jurnal Fisika Unand, 7, 8-14, (2018).

Septiari, P.W., Karyasa, W., dan Kartowarsono, "Pembuatan Papan Partikel dari Limbah Plastik Polyprophylene (PP) dan Tangkai Bambu", Jurnal Kimia Visvitalis Universitas Pendidikan Ganeshai, 2, 117-126, (2014). 
Suroto, "Pengaruh Ukuran dan Konsentrasi Perekat Terhadap Sifat Fisik dan Mekanik Papan Partikel Limbah Rotan", Jurnal Riset Industri Hasil Hutan, 2, 18-30, (2010).

Wibowo, H., Rusianto, T., Ikhsan, M., "Pengaruh Kepadatan dan Ketebalan terhadap Sifat Isolator Panas Papan Partikel Sekam Padi”, Jurnal Teknologi, 1,107-111, (2008). 